\title{
Teatro do Ginásio Uma fábrica de gargalhadas
}

Paula Magalhães

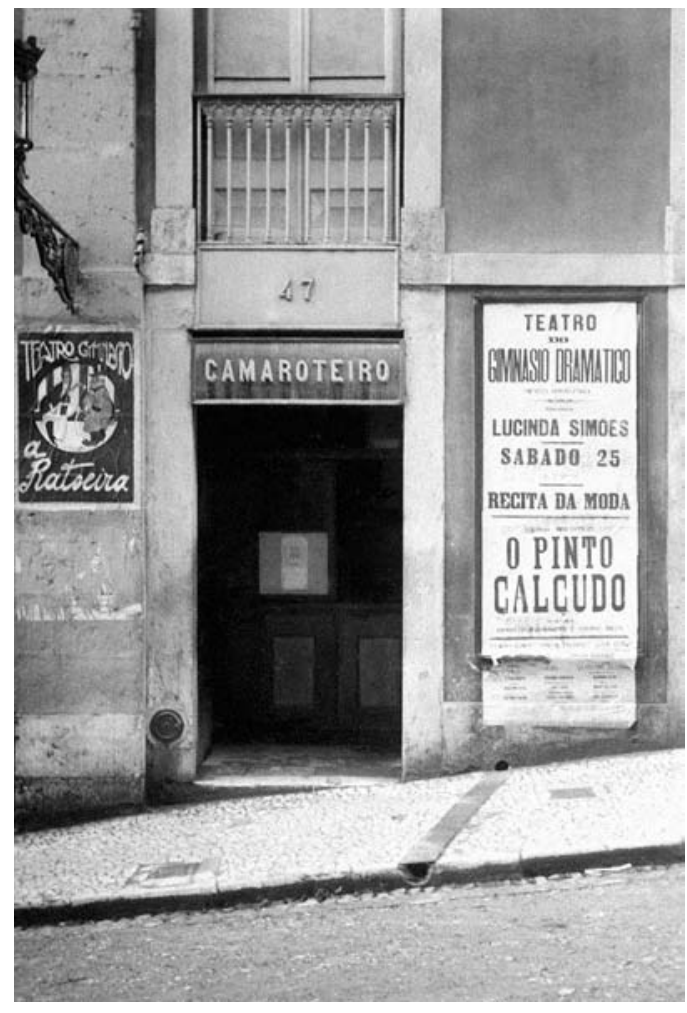

Uma das fachadas que alberga o "Espaço Chiado", em Lisboa, do lado da Rua Nova da Trindade, preserva, ainda hoje, um último vestígio, pálido e quase imperceptível, do que em tempos guardaram aquelas paredes. A inscrição em relevo que nela vislumbramos - Theatro do Gymnasio - permite-nos identificar o propósito da construção do edificio mas deixa-nos a léguas do que aquele nome verdadeiramente significou.

Para isso, há que voltar atrás no tempo e percorrer ao contrário as "estórias" de uma história que remonta a 1845 - ano em que foi erguido um modesto barracão, que começou por ser divertimento circense mas depressa foi transformado em palco da arte declamada -, e termina em 1952, ano que marcou, em definitivo, o fim do espaço como sala de espectáculos.

Ao longo de mais de um século de existência, o Ginásio mudou várias vezes de aparência, foi palco de estrondosos sucessos e de espectáculos que não passaram da primeira representação, viu florescer géneros que se tornaram moda e artistas que se tornaram referência no panorama nacional e foi um dos palcos mais acarinhados da cidade, muito por culpa dos risonhos espectáculos que apresentava.

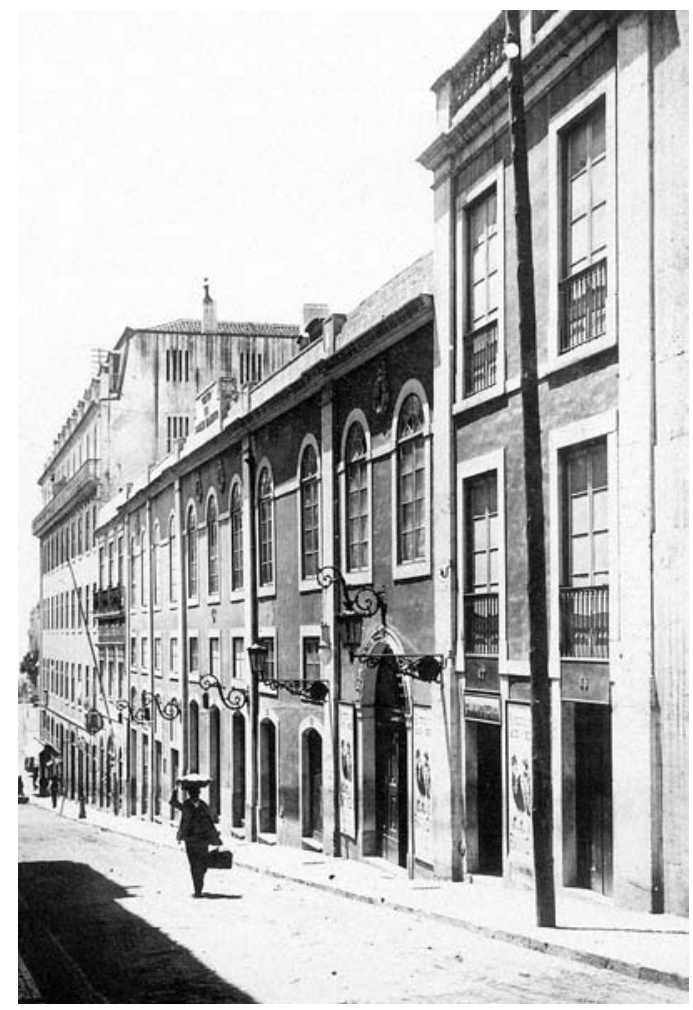

Bilheteira do Teatro do Ginásio (inicio do séc. XX), fot. Alberto Carlos Lima [cortesia do Arquivo Fotográfico Municipal de Lisboa].

Teatro do Ginásio antes de 1921 [cortesia do Arquivo Fotográfico Municipal de Lisboa].

Por ali passaram nomes grandes do teatro como Francisco Alves da Silva Taborda (que debutou naquele espaço no espectáculo de inauguração e se tornou uma das suas "imagens de marca"), José António do Vale (que Ihe seguiu em muitos aspectos as pisadas), Isidoro, António Pedro, Lucinda Simões, Telmo Larcher, Alves da Cunha, Maria Matos, Palmira Bastos, Amélia Rey Colaço, entre tantos outros actores mas também autores e ensaiadores que deixaram marca. Por ali passaram também muitas estrelas do teatro mundial (como Sarah Bernhardt e Ernesto Rossi), estrelas de modas passageiras que não ficaram para a história (como os campanólogos escoceses e as sonâmbulas profissionais), e as estrelas de uma nova arte, o cinema, que a partir de 1932 passou a dividir os aplausos com os espectáculos de teatro.

Porque começou como divertimento circense e enquanto espaço de teatro declamado, pelo menos nos primeiros tempos, não abandonou por completo essa vocação, alternando dramas e comédias com números de variedades, o Ginásio cedo conseguiu a afeição do público mas não as comodidades que seriam desejáveis, acabando por ser as deficientes condições e a pouca experiência de
Paula Magalhães é jornalista da rádio RADAR e investigadora do Centro de Estudos de Teatro num projecto de iconografia- Opsis. 
cento e vinte e dois

Sinais de cena 9. 2008

Arquivo Solto

Paula Magalhães

Teatro do Ginásio: Uma fábrica de gargalhadas alguns artistas a ditarem o caminho daquela que seria a sua principal vocação: a comédia.

Aos poucos, o Ginásio delineava os traços que acabariam por marcar a sua identidade, caracterizada pelos espectáculos que aspiravam simplesmente a divertir o público, pelos actores, autores e tantas outras figuras que se tornaram num ícone indissociável do espaço, pelo público que mais não ansiava que umas horas de boa disposição, e pela afectividade que conseguia reunir à sua volta - sentimento transversal a literatos, jornalistas e políticos (que não dispensavam dois dedos de conversa no foyer), homens de dinheiro ou de boa vontade (que contribuiram para as necessárias remodelações e que tantas vezes o salvaram de um fim precoce), críticos e cronistas (que embora, por vezes, defendessem uma maior dignificação da arte dramática, acabavam por se render à popularidade e boa disposição que emanava do espaço) e actores, autores e tradutores (para quem o palco foi viveiro, escola e símbolo maior de camaradagem).

\section{Os primeiros anos}

0 Ginásio, que começou por se chamar Novo Ginásio Lisbonense, foi erguido em meados da década de 1840, pelas mãos de João José da Mota (tipógrafo e empresário circense), em pleno centro nevrálgico da capital, a dois passos da Lisboa tradicionalista, que habitava uma das zonas altas da cidade - o Bairro Alto e arredores -, e colado à Lisboa elegante, que subia e descia o Chiado, atraida pelas mais finas lojas da capital do reino, por um sem número de cafés onde se reuniam os mais ilustres conversadores da cidade, por clubes e sociedades que organizavam bailes muito bem frequentados e pelo incontornável Teatro de São Carlos, ponto de encontro da aristocracia e burguesia em ascensão, de políticos e homens de letras e de todos os que aspiravam entrar na alta roda da sociedade.
Era um barracão exíguo e sem comodidades de maior, que, embora tentasse piscar o olho à Lisboa culta e janota, cativava maioritariamente a Lisboa tradicionalista, que se divertia com todo e qualquer acontecimento e habitava os bairros populares, escuros, sinuosos, sujos e superpovoados que rodeavam a cidade baixa, traçada a régua e esquadro pelos arquitectos do Marquês de Pombal. Era uma cidade de contrastes, agitada pela instabilidade política que reinava desde a Revolução Liberal de 1820, e onde o desenvolvimento chegava a passo de caracol.

Nascia na Travessa do Secretário da Guerra, a 12 de Outubro de 1845 , só mais tarde renomeada Rua Nova da Trindade, em terrenos do antigo Palácio de Geraldes (propriedade da Irmandade da Igreja de Nossa Senhora do Loreto), para fazer desfilar as mesmas danças, acrobacias, proezas gímnicas e pantomimas que faziam as delícias da Lisboa popular, aos domingos à tarde, durante os meses mais quentes do ano, nas praças circenses do Salitre, Rua da Procissão, Travessa do Abarracamento de Peniche e Circo Nacional Amor da Pátria, com a diferença de ser coberto, o que permitia a realização de espectáculos à noite e durante o Inverno.

Mas talvez porque os apelos que vinham do teatro declamado começaram a ser cada vez maiores, com as animadas lutas entre o Teatro da Rua dos Condes e o Teatro do Salitre (os palcos que em 1845 apresentavam espectáculos com regularidade), pela designação de Nacional e pelo respectivo subsídio que tal designação significava, e a tinta que a construção de um verdadeiro Teatro Nacional fazia correr nos jornais de então, os responsáveis do Ginásio resolveram abandonar as artes circenses, remodelar por completo o barracão e abrir as portas como sala de teatro, em Maio de 1846, cerca de um mês depois da abertura do D. Maria II. 

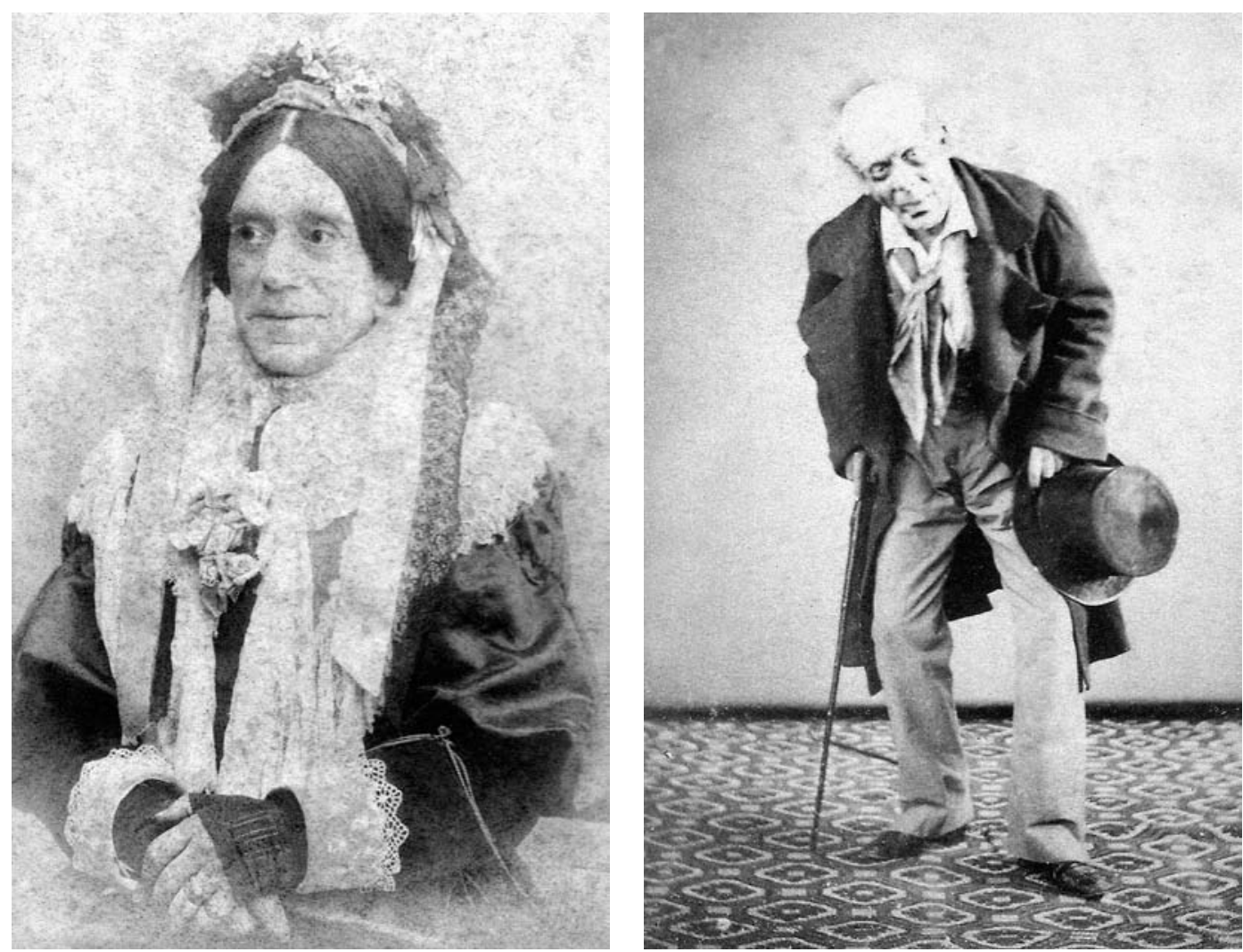

Actor Vale,

A madrinha de Charley

[cortesia do Museu

Nacional do Teatro].

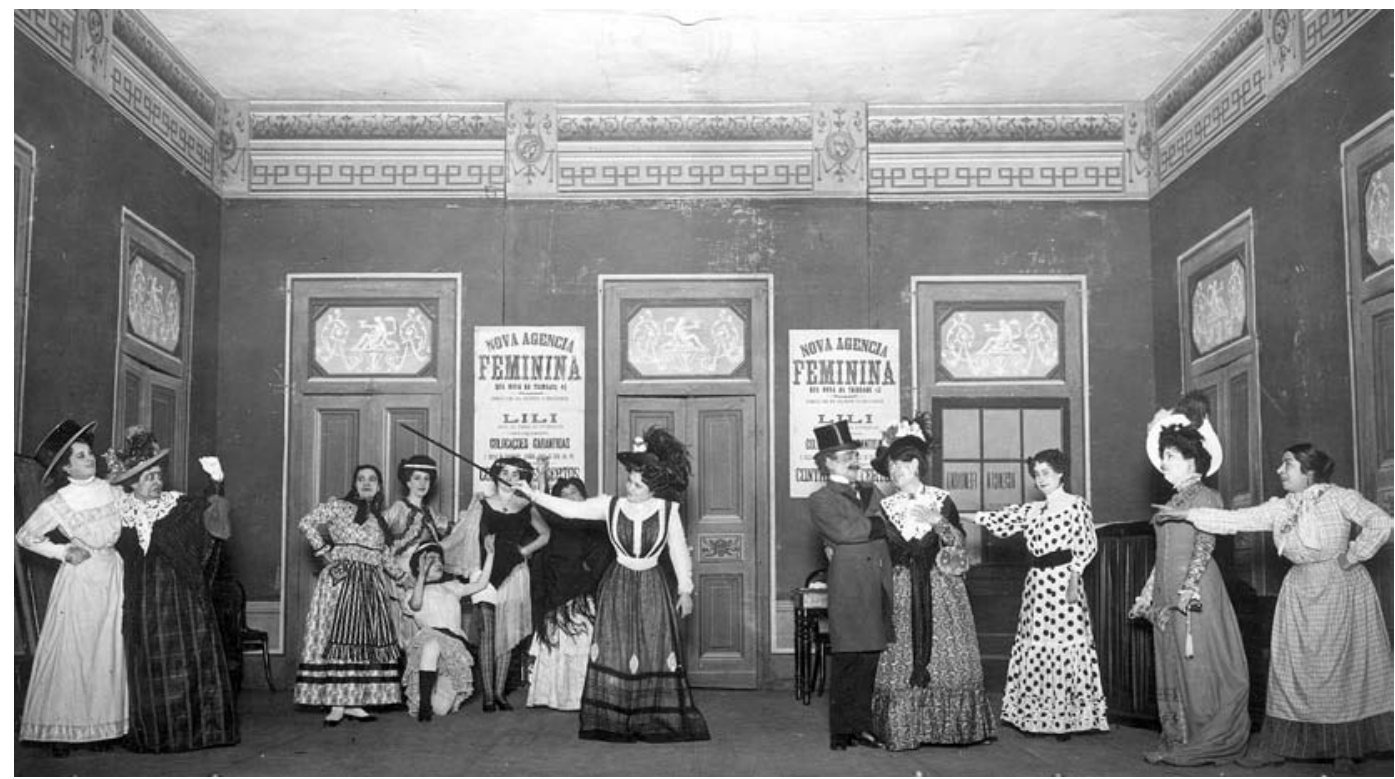

Cena da peça

A nova agência feminina,

1910,

fot. Alberto Carlos Lima

[cortesia do Arquivo

Fotográfico Municipal de Lisboal.

Remodelado de acordo com as disponibilidades financeiras, que na verdade não eram muitas, o espaço, que já tinha sido Novo Ginásio Lisbonense e que os proprietários ainda quiseram que fosse Teatro Nacional Lisbonense, reabria a 16 de Maio de 1846 como Teatro do Ginásio e com a apresentação da peça Paquita de Veneza ou os fabricantes de moeda falsa, ensaiada pelo professor do conservatório César Perini de Lucca. De acordo com o jornal 0 Patriota, de 6 de Junho de 1846, o barracão, que passou a ser também gerido pelo fiscal do Teatro de $\mathrm{S}$. Carlos, Manuel Machado, para além de João José da Mota, tinha sido alvo de uma metamorfose completa.

0 célebre folhetinista Júlio César Machado, que assistiu com o pai ao espectáculo de inauguração, descreve o novo espaço como "um teatrinho de cartas, sem proporções, sem espaço, sem comodidades, mas alegre, simpático, espécie de criança do povo, pobre rotinha e risonha, que dá mais gosto ver que alguns moninhos frisados, embiocados em arminhos, de olhos franzinos e carinha de asnos. Teatrinho de ocasião, que parecia sair de uma habilidade de berliques e berloques! Tinha duas vistas. Uma de bosque, outra de sala. Como nos teatros particulares devia caber tudo e fazer-se tudo ali" (Machado 1878: 13-14).

Embora a política tenha perturbado e muito o primeiro ano de exploração do novo espaço, com a Revolta da Maria da Fonte a obrigar à suspensão das representações, ao encerramento da sala e ao agudizar da já complicada 
situação financeira, o Ginásio foi tentando afirmar-se no dificil firmamento do teatro declamado com a seriedade de dramas políticos ou de lágrima obrigatória, apesar de serem as comédias e as farsas que maior adesão conseguiam por parte do público. Fosse com o intuito de tentar afastar a clientela barulhenta que insistia em frequentar a sala, de apagar de vez a imagem de espaço de divertimento circense ou, simplesmente, de querer ser encarado como teatro sério - à imagem do que então acontecia com o Teatro Nacional - não foi pelo riso que - Ginásio tentou a primeira conquista, facto que quase Ihe custava a sobrevivência.

0 caminho para o inevitável abismo foi travado pela chegada de Émile Doux. 0 francês, que já tinha operado no Condes e no Salitre uma verdadeira revolução na arte de representar, acabou por ser o salvador do Ginásio, devolvendo-Ihe o público e orientando-o para o que viria a ser procurado e lembrado.

Facilmente Doux percebeu que não tinha nem condições fisicas nem humanas para dramas de fôlego, passando desde então a dedicar-se às comédias, género para o qual o palco servia na perfeição, e no qual os actores do Ginásio se movimentavam com maior facilidade. Imitadas ou traduzidas do francês, de enredo simples mas recheado de peripécias, satisfaziam o público que passou a visitar com maior frequência a sala.

Durante o tempo em que dirigiu e encenou a Companhia do Ginásio (entre Agosto de 1847 e Setembro de 1848), a sala da Travessa do Secretário da Guerra apresentou cinco dramas, um melodrama, uma farsa e nada mais nada menos que 45 comédias, 26 das quais em um acto.

A consolidação como espaço de comédia - com a imprensa a determinar que o choro ficaria, a partir de então, reservado para o Rossio (Teatro Nacional), e o riso para a Travessa do Secretário da Guerra (Teatro do Ginásio) - conferiu aos actores a segurança suficiente para se aventurarem por géneros menos explorados em Portugal, como a ópera-cómica, ou praticamente desconhecidos, como a revista.

A aposta na ópera-cómica e na farsa lírica ditou o fim da colaboração de Émile Doux com o Ginásio, por este não concordar de todo com a ideia, e fez tremer a crítica mais conservadora, admirada com a ousadia do teatro em querer cantar árias e duetos a escassos metros da "catedral", mas acabou por ajudar a elevar o Ginásio à categoria de "templo" da diversão e do riso.

As coplas d'A Marquesa e d'O conselho das dez, compostas pelo maestro António Luís Miro, com libreto de Paulo Midosi, andaram de boca em boca, o Simplício Paixão que Francisco Alves da Silva Taborda encarnava n'A velhice namorada sempre leva surriada, de Francisco Xavier Pereira da Silva, catapultou-o para o sucesso, e a paródia de Francisco Palha à ópera Lúcia de Lamermoor, de Donizetti, foi reposta vezes sem conta no Ginásio, sempre com o mesmo sucesso.
Quanto à revista, embora não tenha sido nem dos géneros mais explorados nem dos que maior adesão teve por parte do público, merece a referência por ter sido ao palco do Ginásio que, pela primeira vez em Portugal, subiu um espectáculo apelidado como tal: a 11 de Janeiro de 1851 o Teatro do Ginásio estreava a revista em 3 actos Lisboa em 1850, uma espécie de retrospectiva, em tom cómico e crítico, dos principais acontecimentos do ano anterior.

\section{Os dias alegres}

0 sucesso crescente, com as óperas-cómicas e as revistas a coabitarem no Ginásio com farsas e dramas, mas maioritariamente com comédias ligeiras e de riso fácil, transformou o barracão da Travessa do Secretário da Guerra num dos mais concorridos teatros da capital, frequentado por gente "de todas as classes e de todos os sexos" (A Semana Teatral, 06.02.1851: 35), e obrigou a melhoramentos sucessivos na sala que, em 1852, significariam mesmo a construção de um novo edifício.

0 barracão deu lugar a um elegante edifício em alvenaria, com vários corpos a comunicarem entre si, construído devido aos préstimos de muitas personalidades: Rodrigo da Fonseca Magalhães (à data responsável pelo Ministério do Reino), que auxiliou dando créditos à nova empresa; os cenógrafos Rambois e Cinatti, que se prontificaram, gratuitamente, a desenhar a planta e a dirigir os trabalhos; o empreiteiro Francisco Ruas, que forneceu todo o material e pagou os ordenados aos operários; os fornecedores que se prontificaram a entregar o material e a mais tarde receber o pagamento; e a família real, que, para além de visitar as obras, terá alugado dois camarotes, mandando-os ornar e mobilar à sua custa.

0 periódico A revolução de Setembro escreveu, na altura, que o novo teatro não se assemelhava a nenhuma outra casa de declamação e que as suas decorações revelavam bem "a inteligência de quem as dispôs" (09.09.1852: 2), enquanto o Gil Vicente destacava a beleza do tecto, o desafogo e a disposição dos camarotes (em número de três ordens), os assentos de palhinha da plateia e a iluminação a gás (10.11.1852: 4). Foi este o Ginásio das muitas glórias que Lisboa conheceu durante muitos anos.

$\mathrm{Na}$ realidade, bastariam os anos do exíguo barracão para que os espectáculos apresentados no Ginásio ficassem para a história como autênticas "aulas de alegria", classificação atribuída por Júlio César Machado no tempo em que Émile Doux ali ensaiava "as comédias mais engraçadas do repertório de França", mas, acabou por ser essa a ideia que prevaleceu ao longo dos anos, aliada às "propriedades curativas" que os mesmos espectáculos evidenciavam, capazes que eram, como proclamava a imprensa da altura, de aliviar, durante umas horas, os males do dia-a-dia. Originais ou traduções, ao Ginásio interessavam comédias que seguiam um modelo capaz de divertir a assistência, fazendo-a esquecer, ainda que momentaneamente, o cansaço e as agruras da vida. 


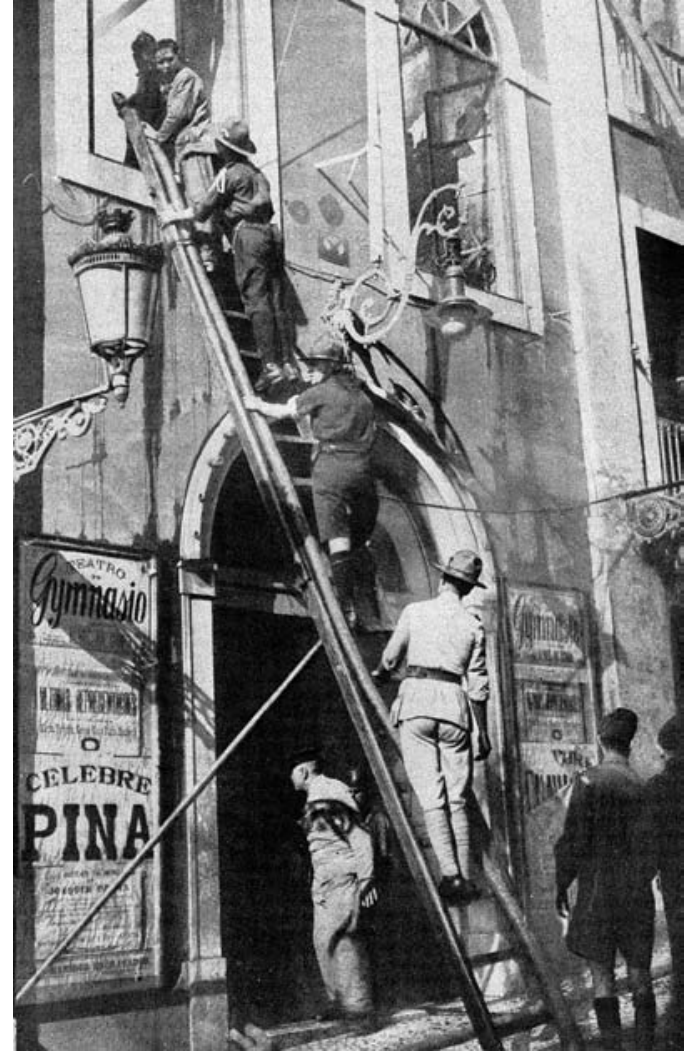

Os críticos apelidavam-nos de "fábricas de gargalhadas", resumindo desta forma entrechos impossiveis de descrever, já que era nos quiproquós, no ilógico da acção, no imprevisto das cenas e das personagens, que encontravam interesse e graça.

Não faltavam no Ginásio comédias simples e de enredo engraçado como A sonâmbula sem o ser (1853), 0 juiz eleito (1854), Duas bengalas (1854) ou Por causa de um emprego (1855), e outras que, apesar de totalmente desprovidas de valor literário, tinham o condão de "divertir os espectadores, tanto pela engraçada variedade dos lances, como pela muita vida que ha[via] na sua acção" (Revista dos espectáculos, Fevereiro de 1856: 28), como Sonambulismo e pimenta (1856), à qual a revista se refere O vilão em casa do seu sogro (1856) ou Uma novela em acção (1859), onde tudo era absurdo, tudo era monstruoso de disparate e, todavia, o público tinha de "estar a rir durante os três actos, para evitar o incómodo de rir de instante a instante" (Revista de Lisboa, 28.10.1858: 2).

Muitos surpreendiam-se com as casas cheias do Ginásio, em oposição ao aspecto desolador que o elegante D. Maria II muitas vezes apresentava, outros foram-no proclamando "palco da boa disposição", "albergue da gargalhada" ou "fábrica de riso", epitetos que manteve até ao início do séc. $X X$, sem que fossem evitados, ao longo dos anos pequenos deslizes naturais, que respondiam a seduções passageiras, vontades de artistas de renome ou às mudanças a que o tempo e a arte sempre obrigam.

Com a construção do novo edifício, em 1852, o público do Ginásio generalizou-se por completo, rendido a um repertório de peças divertidas e ligeiras, passando a ser definido, mais do que pela classe social a que pertencia, pelas intenções que o levavam a frequentar aquele espaço: a boa disposição e o riso fácil das comédias que ali eram apresentadas.

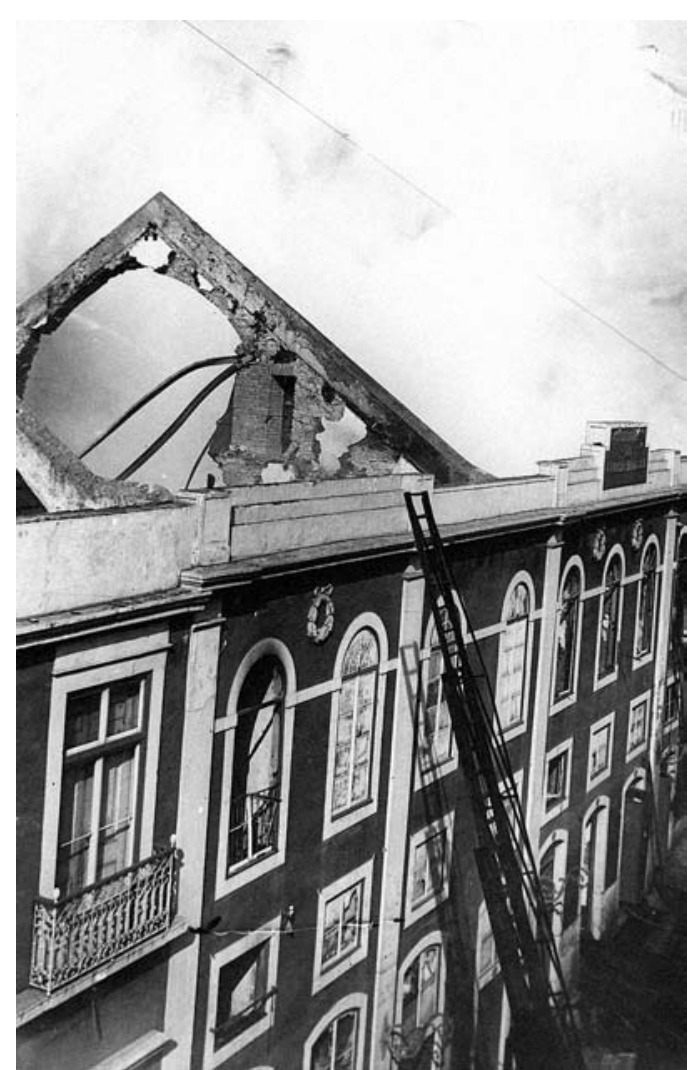

Os bombeiros combatem o incêndio do Teatro do Ginásio, fot. Salgado, in Ilustração Portugueso (12.11.1921: 370).

Incêndio no Teatro do Ginásio, 1921, fot. Ferreira da Cunha [cortesia do Arquivo Fotográfico Municipal de Lisboa].

Ajudavam às enchentes, as cenas cómicas e as cançonetas do actor Taborda, que não podia adoecer nem partir em digressão pela província que a casa logo se ressentia, e o repertório do actor Vale, que, embora ainda estivesse em início de carreira, já era acolhido com muito apreço por parte de um público que cedo Ihe adivinhou o talento.

Com o passar dos anos, o Ginásio foi vivendo altos e baixos, com o repertório a espelhar, por vezes, ou a instabilidade da gestão (só solidificada em 1878 quando José Joaquim Pinto tomou conta dos destinos do teatro) ou o constante sai e entra de actores, que muito determinavam as peças que eram levadas à cena, mas conseguiu manter o pedestal de "fábrica de riso", de onde só viria a ser desalojado poucos anos antes do incêndio que o destruiria por completo, em 1921, não porque a cidade tivesse encontrado um substituto à altura, mas apenas porque os palcos do século XX deixaram de obedecer à lógica que prevaleceu durante boa parte da segunda metade do séc. XIX, que "arrumava" os dramas e as tragédias no Nacional, as operetas no Trindade (a partir de 1867) e as comédias no Ginásio.

Quando José Joaquim Pinto tomou as rédeas do Ginásio, cargo que ocupou entre Julho de 1878 e Maio de 1904, tinha a seu lado Leopoldo de Carvalho, como ensaiador, e António Sant'Ana, na bilheteira, figuras que a história do teatro confirma terem sido os dois grandes auxiliares da empresa. Durante este período, o Ginásio viveu outra das suas épocas áureas, primeiro com as comédias de Gervásio Lobato e Eduardo Schwalbach e depois com as traduções que Freitas Branco fazia de originais alemães.

A critica mais moralista insurgia-se, por vezes, contra espectáculos que pouco contribuiam para a educação e virtuosidade do povo, a mais fundamentalista protestava 
contra o menor desvio da comédia e a mais literária, embora desejasse ver no palco comédias de outra elevação, por serem boas para a arte e para a educação do gosto do público, acabava em alguns casos por concluir que, se tal acontecesse, ficaria a plateia às moscas e a empresa a morrer à fome, pelo que o melhor seria continuar a promover o riso, sem preocupações de professor de instrução primária. As peças do Ginásio podiam não agradar à critica mais exigente mas agradavam seguramente ao público, que demonstrava o seu apreço enchendo a plateia e os camarotes do teatro.

Em 1890, encheu o Ginásio até não mais poder por culpa de Gervásio Lobato e do seu Comissário de polícia, peça que passaria a figurar na prateleira das que constituiam a "imagem de marca" daquele espaço, tantos foram os anos que se manteve em cena. Outras até então tinham conseguido o mesmo estatuto, partilhado com actores, autores, ensaiadores e tantas outras figuras que, pela sua associação ao Ginásio, ajudaram a definir uma identidade e uma memória, indissociável do espaço e da sua história.

\section{Imagens de marca}

Actores como Taborda e Vale foram, cada um a seu tempo, a imagem do Ginásio, o seu principal sustentáculo e uma fonte inesgotável de alegria, muito para além dos espectáculos que protagonizavam.

Não eram de estranhar as enchentes sempre que Taborda apresentava uma das inúmeras cenas cómicas José do Capote, Amor pelos cabelos, 0 tio Mateus ou Ventura, o bom velhote - ou os cartazes anunciavam coroas de glória do actor Vale - A madrinha de Charley ou Comissário de polícia -, como não eram de estranhar as salas vazias cada vez que um dos dois ficava doente ou resolvia partir para mostrar os seus talentos noutras paragens.

Para Taborda, o Ginásio foi o teatro onde debutou, onde cresceu para a arte de representar, onde criou o seu repertório e onde a sua glória foi sempre maior do que as dimensões da pequena sala. Júlio César Machado, que the esboçou a biografia em 1871, escreveu ter muitas vezes corrido o boato de que abandonaria o Ginásio para entrar no D. Maria, mas isso não chegou a acontecer, "felizmente para o Ginásio, que morreria nessa hora, felizmente talvez para Taborda mesmo, que morreria horas depois" (Machado 1871: 43).

Representou sempre enquanto pôde, sem que a surdez ou a velhice fossem impedimento, não negava um convite para um espectáculo, promovia benefícios em favor dos mais desfavorecidos, estendia a mão a todos os jovens aspirantes a actores e, até ao ano da sua morte, abriu todas as temporadas do Ginásio, ora com a cançoneta de Paulo Midosi Ventura, o bom velhote, ora com o cómico Tio Mateus. Sempre que o fazia, tinha à disposição o seu velho camarim, que só ele podia abrir nos dias de representação.
À imagem de Taborda, também o actor José António do Vale viu o seu destino intrinsecamente ligado à história do Ginásio, primeiro como escola, depois como trono de glória, e, mais tarde, como empresário. Ficou conhecido como "o Vale do Ginásio", embora tenha passado uma longa temporada no Brasil e tenha mostrado o seu talento fora do palco da Rua Nova da Trindade. Quando no início do séc. XX escreveu sobre o Ginásio, Alfredo de Mesquita não hesitou em afirmar que o actor fazia parte daquele teatro "como o tronco faz parte da árvore ou o telhado faz parte da casa" (Mesquita 1994: 136).

Gervásio Lobato, e o seu fiel seguidor, Eduardo Schwalbach - dois dos mais aplaudidos comediógrafos de finais do Séc. XIX - ao proporcionarem no Ginásio sucessivas enchentes, com os mais dignos exemplares do período de ouro da comédia portuguesa, tornaram-se, também eles, um símbolo daquela sala, da mesma forma que os ensaiadores Romão e Leopoldo de Carvalho, cujo estilo pessoal passou a ser o estilo do teatro, foram muitas vezes considerados entidades inseparáveis do palco onde apresentavam o seu trabalho. Se um faltasse como complemento do outro, ambos os elementos se ressentiriam.

São figuras que representam, todas elas, pedaços da identidade do Ginásio, pelo que foram, pelo trabalho que ali desenvolveram mas, principalmente, por com ele terem estabelecido uma importante relação de afectividade, sentimento partilhado por muitos dos que ajudaram a perpetuar a memória do espaço.

Essa "imagem de marca" pode ainda ser encontrada numa certa tipologia de espectáculos - comédias ligeiras, muitas vezes episódicas, que retratavam a vida burguesa de então, castigando de modo brando alguns dos seus costumes, com o simples objectivo de divertir a audiência - no público que frequentava o teatro - que sempre ali procurou umas horas de distracção - ou na forma como, durante muito tempo, a sala funcionou como espaço de sociabilidade, substituindo o café para a cavaqueira de muitos intelectuais.

\section{Um palco de afectividades}

Embora praticamente não figurasse na lista dos expoentes máximos da arte dramática em Portugal, devido à menor qualidade literária dos espectáculos apresentados, o Ginásio raras vezes se queixou da falta de afeição, por parte dos actores que ali apresentaram o seu trabalho - que encontravam naquele espaço um espirito de camaradagem, uma vivência acolhedora e uma atmosfera de simpatia sem igual -, por parte de jornalistas e homens de letras - que frequentavam assiduamente a plateia e os bastidores daquela sala, cavaqueando sobre questões de arte ou de estética, sobre uma causa de tribunal ou um artigo de jornal literário, morte ou casamento, mudança de ministério ou farsa nova" (Machado 1878: 23) -, por parte do público indiferenciado - , que procurava uns momentos de distracção ao fim de um dia de trabalho -, e até por parte 


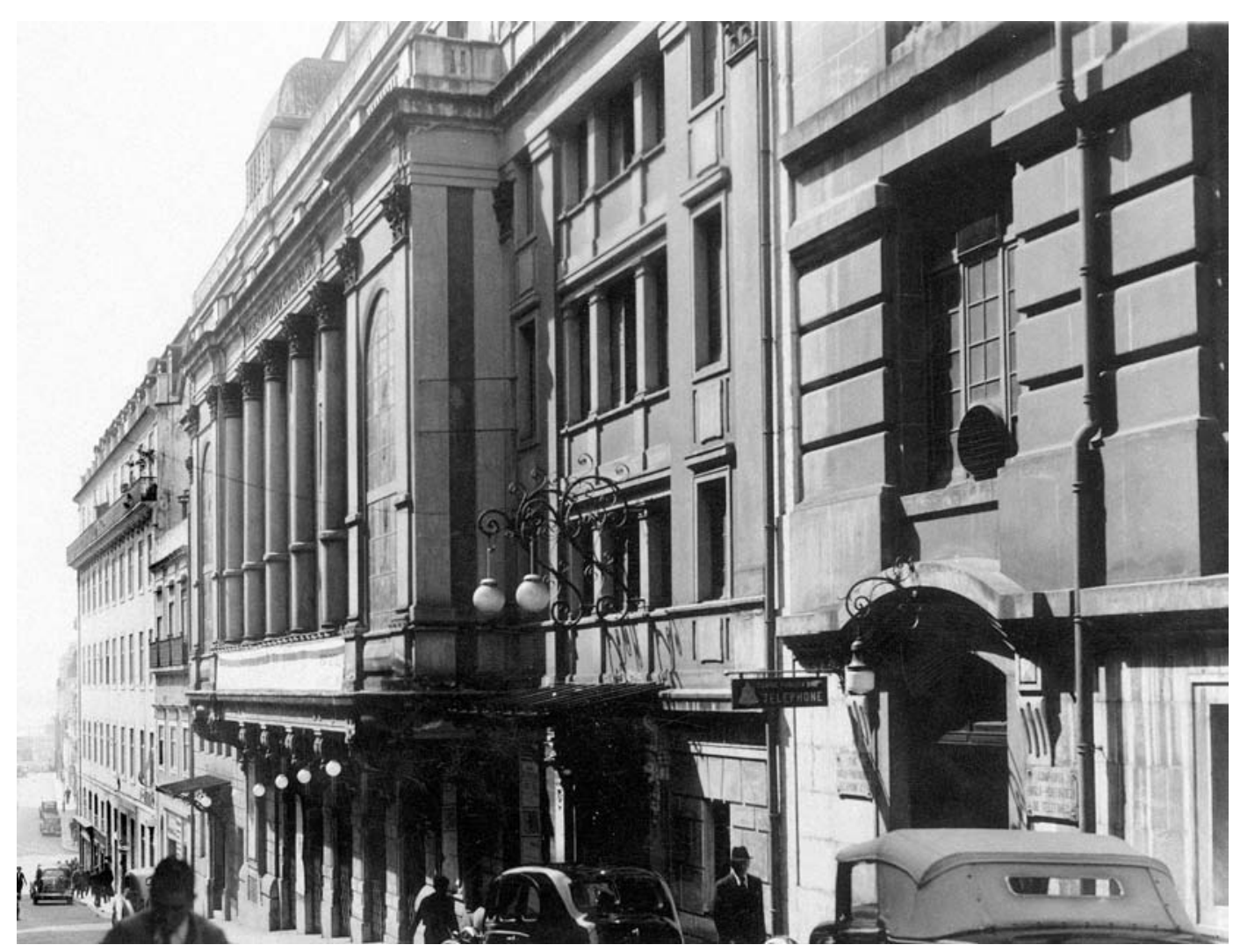

Teatro do Ginásio em

1944 (ainda em

funcionamento),

fot. Eduardo Portugal [cortesia do Arquivo Fotográfico Municipal de Lisboa].

de críticos e folhetinistas, que procuravam uma maior elevação da arte de Talma.

Surpreendia-se o crítico d'A semana teatral por ver, ainda no tempo do barracão, o que apelidava de "asquerosa espelunca", "cabaret mascarado", "cocheira metamorfoseada em teatro" e "indecente casebre" a transbordar de uma audiência que ria e folgava, quando no elegante D. Maria II eram apresentadas peças como Frei Luís de Sousa ou O casal das giestas (28.10.1851: 8), enquanto o cronista Francisco Maria Bordalo se mostrava convicto de que as peças de Racine e Corneille

"afugentariam os espectadores ou seriam barbaramente pateadas", já que a melhor sociedade da capital era levada, pela moda, para a ópera italiana do S. Carlos, e as classes inferiores preferiam "os teatros de vaudeville ou mesmo os arlequins e cavalinhos, à representação de um drama conscienciosamente escrito", deixando às moscas as salas que ficassem entre estes dois extremos, como o D. Maria II (Bordalo 1855: 56 e 57).

Embora o modelo de espectáculos do Ginásio não cumprisse os requisitos da maioria dos críticos, que preferiam comédias "finas", "delicadas", "bem urdidas" e "com excelentes tipos", muitos acabavam por se render às opções do teatro pelos enredos movimentados das comédias de costumes, por estas resultarem numa melhor saúde financeira para a empresa. Ao comparar, em 1883, a comédia Testamento de César Giradot, apresentada no D. Maria, com as peças A casamenteira e Rua da Paz n. ${ }^{115}$ a apresentadas no Ginásio, Cristóvão de Sá concluia que "com a do D. Maria não se ri a gente e acha-a boa", enquanto "com as do Ginásio ri-se a plateia a bandeiras despregadas e no fim de contas não achou nada lá dentro" (A revolução de Setembro, 09.01.1883: 1). Pouco tempo antes, o folhetinista já tinha dado razão às empresas que, nos teatros não subsidiados, apimentavam os menus ao gosto do público, como fazia o Ginásio, mesmo quando só arrancavam da crítica os habituais epitetos: "fábrica de gargalhadas", "sucesso doido", "comédia desopilante", "de fazer rebentar o riso".

0 Ginásio era a descrição perfeita de um teatro assumidamente popular, com as divertidas representações a elevarem-no à condição de preferido na cidade. Nas páginas da publicação Perfis artísticos, Caetano Pinto demonstrava o sentimento que percorria muitos dos que frequentavam a plateia do Teatro do Ginásio: "a gente entra na plateia do Ginásio como quem entra na sala da sua casa, numa continuação do jantar, alegre e satisfeito de família. Não concordam? Ali - no Ginásio - encontramos os nossos amigos do café, os nossos companheiros de trabalho e às vezes os nossos antigos condiscipulos. (....) Há boa disposição, vai-se precavido contra as triades medonhas dos Ennery, não se está para pensar os longos enredos fastidiosos e impossiveis dos dramalhões. Vai-se ali para se rir, para passar a noite. Vou eu, vais tu, vão todos. Que bela plateia a do Ginásio" (Outubro, 1881: 5).

\section{Os últimos anos}

Porque se tratava de um espaço não subsidiado, com os cofres sujeitos aos apetites do público, à boa ou má gestão dos empresários e a constrangimentos políticos e sociais, as dificuldades financeiras acabaram sempre por marcar a sua história, condicionando melhoramentos, opções de repertório e a constituição de elencos. No entanto, embora Ihe faltassem o dinheiro, a tecnologia de ponta e as comodidades que o vizinho do lado, o Teatro da Trindade, ostentava, nunca Ihe faltaram as pessoas e nunca Ihe faltou a boa disposição.

Nunca... até à madrugada de 6 de Novembro de 1921, quando as chamas reduziram a escombros o espaço edificado em 1852. 
Vivia o Ginásio dias que lembravam a folia de outros tempos, com a comédia 0 célebre Pina, que proporcionava boas enchentes à casa e satisfação à companhia Alves da Cunha, quando foram outras as chamas que irromperam, reduzindo a cinzas as paredes e os "dias alegres" da sala da Rua Nova da Trindade.

Os jornais lamentaram a perda do velho e glorioso teatro e discorreram sobre a mágoa de ver desaparecer, pouco a pouco, as salas de espectáculos de Lisboa, rendidas umas ao fascinio da sétima arte, consumidas outras pelas chamas.

Não se perderam as glórias passadas, porque essas ficam registadas na memória, mas poucas foram as glórias dignas de registo do presente que começou em 1925, ano da inauguração do "quarto" Ginásio. Ao novo espaço não faltava o luxo, a tecnologia nem a comodidade, mas passaram a faltar a alegria e também as pessoas.

Quando o teatro reabriu as portas, totalmente renovado, o público demonstrou, durante alguns anos, querer continuar a acompanhar de perto o trabalho que ali era desenvolvido, mas, porque os tempos começavam a mudar e com ele também as artes, o cinema acabou por tomar conta do Ginásio, da mesma forma que já tinha tomado conta de outras salas como o Teatro da Rua dos Condes, o Politeama e o São Luiz: assim nascia, em 1932, o Cine-Ginásio.

Apesar de as artes dramáticas intercalarem, a espaços, com as luzes da ribalta cinematográfica - porque assim o exigiam as disposições legais dos espaços classificados oficialmente como cine-teatros - com o passar dos tempos, as projecções acabariam por ofuscar quase por completo as estrelas do palco.

0 início dos anos 50 marca o fim da vida do Teatro Ginásio, cujo interior foi, anos depois, completamente demolido para dar lugar a um espaço comercial. No entanto, porque outras disposições legais não permitiam que um recinto de teatro pudesse ser ocupado para outros fins, as obras foram embargadas e assim se mantiveram durante muitos anos.

Em 1980, o Teatro do Ginásio foi considerado imóvel de interesse público pela Câmara Municipal de Lisboa mas, porque o interior há muito que estava demolido, a classificação abrangia apenas a fachada do edifício, motivo pelo qual ainda hoje se mantém intacta.

0 edifício acabaria por ser adquirido pelo grupo GrãoPará Agromá, que decidiu colocar em marcha o projecto de construção de um centro comercial onde, possivelmente para contornar a já referida lei, seria também construída uma sala-estúdio. A 7 de Outubro de 1992 era inaugurado o "Espaço Chiado - Centro Comercial e Cultural Theatro do Gymnasio", com 67 lojas, 28 escritórios e um CineTeatro.

Os corredores labirinticos e as lojas maioritariamente vazias que preenchem hoje o que outrora foi o Ginásio, contrastam com o relato de dias alegres que o teatro viveu durante muitos anos, mas não apagam a memória da boa disposição que reinava no foyer, no palco e na plateia, os aplausos que as comédias bem dispostas sempre arrancavam do público e a glória de, em tempos, ter sido um dos mais populares teatros da capital, acarinhado inclusive por quem defendia uma elevação das artes de palco a patamares a que o Ginásio não se atreveria ascender.

0 Ginásio nunca contribuiu particularmente para a dignificação pela qual alguns literatos se batiam, mas sempre respondeu aos desejos de boa parte do público de então, com espectáculos de riso obrigatório, fossem comédias, óperas-cómicas, vaudevilles, paródias, revistas, cançonetas ou cenas cómicas.

Durante muitos anos, o Ginásio conservou o epiteto de "fábrica de riso", perpetuando a imagem de um teatro de comédia que apesar das dificuldades, sempre soube manter a alegria como tradição, no palco, na plateia e nos bastidores.

\section{Referências bibliográficas}

BASTOS, Glória / VASCONCELOS, Ana Isabel P. Teixeira (2004), 0 Teatro em Lisboa no tempo da Primeira República, Lisboa, IPM, Museu Nacional do Teatro.

BASTOS, Sousa (1947), Lisboa Velha, Sessenta anos de recordações: 1850 a 1910, Lisboa, Oficinas Gráficas da Câmara Municipal de Lisboa.

-- (1994), Dicionário de teatro português (Reprodução facsimilada da $1 .{ }^{2}$ edição 1908), Coimbra, Minerva.

BORDALO, Francisco Maria (1855), Viagem à roda de Lisboa, Lisboa, Tipografia da Rua dos Amadores, 31.

CARNEIRO, Luis Soares (2002), Teatros portugueses de raiz italiana, dissertação de doutoramento policopiada, apresentada à Faculdade de Arquitectura da Universidade do Porto.

CARVALHO, João Pinto de (1898/1899), Lisboa de outros tempos (3 volumes), Lisboa, Livraria de António Maria Pereira.

COSTA, Mário (1950), Feiras e outros divertimentos populares de Lisboa, Lisboa, Municipio de Lisboa.

DIAS, Marina Tavares (1990), Lisboa desaparecida, vol. 2, Lisboa, Quimera. MACHADO, Júlio César (1871), Homenagem a Taborda: Esboço biográfico do actor Francisco A. da S. Taborda, Porto, Imprensa Portuguesa.

-- (1878), Apontamentos de um folhetinista, Porto, Tipografia da Companhia Literária.

-- (1884), Lisboa de ontem, Lisboa, Empresa Literária.

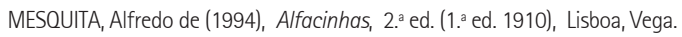

NORONHA, Eduardo de (1922), Estroinas e estroinices: Ruina e morte do Conde de Farrobo, Lisboa, João Romano Torres.

REBELLO, Luiz Francisco (s. d.), Dicionário do teatro português, Lisboa, Prelo. RIBEIRO, M. Felix (1978), Os mais antigos cinemas de Lisboa: 1896 - 1939, Lisboa, Instituto Português de Cinema, Cinemateca Nacional.

SEQUEIRA, Gustavo de Matos (1916), Depois do terramoto, vol. 2, Lisboa, Academia das Ciências.

-- (1939), O Carmo e a Trindade: Subsídios para a história de Lisboa vol. 3, Lisboa, Câmara Municipal.

VASCONCELOS, Ana Isabel P. Teixeira de (2003), O Teatro em Lisboa no tempo de Almeida Garrett, Lisboa, IPM, Museu Nacional do Teatro. 


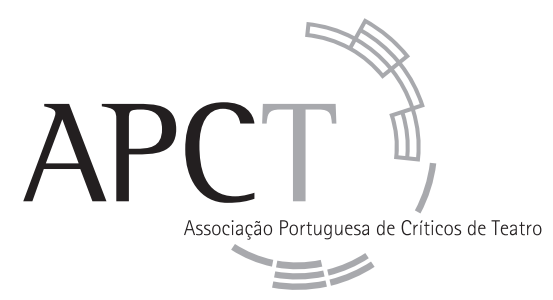

Presidente honorário $\mid$ Carlos Porto

\begin{tabular}{c|l} 
Direcção & $\begin{array}{l}\text { Maria Helena Serôdio } \\
\text { Paulo Eduardo Carvalho } \\
\text { João Carneiro }\end{array}$ \\
Assembleia Geral & $\begin{array}{l}\text { Luiz Francisco Rebello } \\
\text { Sebastiana Fadda }\end{array}$ \\
Conselho Fiscal & $\begin{array}{l}\text { Ana Isabel Vasconcelos } \\
\text { Mónica Guerreiro } \\
\text { Rui Pina Coelho }\end{array}$ \\
$\begin{array}{l}\text { Capitulo Primeiro (Da Associação e dos seus fins) } \\
\text { Art. 2.0 }\end{array}$ & $\begin{array}{l}\text { A Associação tem por objectivo: } \\
\text { Dignificar, estruturar e responsabilizar a actividade crítica relativa à teoria e prática do teatro, } \\
\text { entendendo-se por actividade crítica não só a critica de espectáculos, mas também tudo aquilo que } \\
\text { diga respeito à informação, reflexão e teorização no campo das artes performativas. }\end{array}$
\end{tabular}

\section{Colaboração com Sinais de cena}

A revista está aberta à participação de quem deseje colaborar enviando artigos que julgue corresponderem aos objectivos da publicação e às modalidades enunciadas pelas rubricas existentes. A consulta do sítio da APCT na Internet (www.apcteatro.org) e o contacto por correio electrónico (geral@apcteatro.org ou estudos.teatro@fl.ul.pt) são indispensáveis para conhecer as normas de apresentação dos artigos (dimensão, aspecto gráfico, citações, referências bibliográficas, ilustrações, etc.).

\section{ASSINATURA}

Desejo subscrever os números 10 e 11 da revista Sinais de cena (correspondentes a Dezembro de 2008 e Junho de 2009), no valor total de $22,00 €$ beneficiando assim de um desconto sobre o preço de venda ao público. Fora do pais: Europa $24,00 €$ / Fora da Europa $26,00 €$.

Nome:

Morada:

Código postal: $\quad$ Pais:

Endereço electrónico:

\begin{tabular}{ll|l} 
Forma de pagamento: $\quad \square$ Vale postal $\quad \square$ Cheque $n^{\circ}$. & Banco
\end{tabular}

(passar à ordem de Associação Portuguesa de Críticos de Teatro)

Preencha e envie este cupão (ou fotocópia do mesmo) para:

Data: 
